\title{
Експертно-правові особливості несприятливого лікарювання в хірургії
}

\author{
V. V. FRANCHUK \\ I. Horbachevsky Ternopil State Medical University
}

EXPERT-LEGAL PECULIARITIES OF SURGICAL MALPRACTICE

\begin{abstract}
У статті вивчено поширеність, особливості, причини та наслідки неналежного надання медичної допомоги на підставі дослідження матеріалів судово-слідчих справ, порушених проти лікарів-хірургів, і виконаних відповідно до цих справ комісійних експертиз у Тернопільському обласному бюро судово-медичної експертизи за 2007-2016 рр. Недоліки у наданні медичної допомоги хірургічним хворим виявлено в 90,6 \% експертиз за “лікарськими справами”. Неналежне виконання професійних обов’язків допускали зазвичай хірурги районних і міських лікарень та поліклінічних відділень, під час надання медичної допомоги хворим з ургентною хірургічною патологією, серед якої переважали пацієнти з травмою органів грудної і черевної порожнин. Частіше за все хірурги припускались діагностичних помилок, питома вага яких серед інших дефектів медичної допомоги склала 35,4 \%, помилок у веденні медичної документації (23,5 \%), лікувально-тактичних помилок (20,6 \%), організаційних (17,6 \%), деонтологічних (2,9\%). Помилкові дії лікарів рідко були одиничними, зазвичай асоціюючись між собою. Недостатній обсяг хірургічної допомоги встановлено серед 47,7 \% справ, неправильність ії надання - у 33,3 \%, несвоєчасність медичної допомоги констатовано у 19,0 \% випадків. Дефекти стосовно якості медичної допомоги лікарями-хірургами зустрічались як поодиноко, так і комбіновано. Недоліки у наданні медичної допомоги хірургічним хворим майже завжди $(93,7$ \%) супроводжувались тяжкими для пацієнтів наслідками: смертю, тяжким тілесним ушкодженням або тілесним ушкодженням середнього ступеня тяжкості. Неналежні дії хірургів, які перебували у причинно-наслідковому зв’язку із несприятливими наслідками, констатовано в 40,6 \% випадків експертиз.
\end{abstract}

The prevalence, characteristics, causes and consequences of the misuse of surgeon care, based on the studies of materials of law enforcement cases, brought against surgeons, and commission examinations in the Ternopil Regional Bureau of the Forensic Examination during 2007-2016, according to the cases were studied in details in the article. Deficiencies in health care for surgical patients were detected in $\mathbf{9 0 . 6} \%$ of examinations for "Doctoring". Disadvantages of medical care generally were committed by district and city hospitals surgeons and outpatient departments during the healing process of patients with urgent surgical pathology, with prevailance among patients with trauma of the chest and abdomen. Most often the surgeons made diagnostic errors, their share among other defects of medical care was $35.4 \%$, errors in the conduct of medical records - $(23.5 \%)$, medical and tactical errors - (20.6 \%), institutional errors - (17.6 \%), ethical errors - (2.9 \%). Doctors' errors were rarely isolated, usually associating with each other. Insufficient surgical care was found in $47.7 \%$ of cases, irregularity provided surgical care - in $33.3 \%$ of cases, untimely medical aid - in $\mathbf{1 9 . 0} \%$ of cases. Defects in the quality of surgical care were met both singly and in combination. Deficiencies in health care for surgical patients almost always $(93.7 \%)$ were accompanied by serious consequences: death, serious injury or injury of moderate severity. Surgeons' errors, which were in the causation with serious consequences, were found in $\mathbf{4 0 . 6} \%$ of examinations.

Постановка проблеми і аналіз останніх досліджень та публікацій. Професійна діяльність лікаря не завжди буває вдалою, нерідко супроводжується певними недоліками, які закінчуються негативно, що стає підставою для порушення кримінальних чи цивільних справ [1, 2, 3]. Оцінка якості медичної допомоги, виявлення дефектів у іiї наданні, вивчення особливостей неналежної медичної діяльності надзвичайно важливі як для клінічної медицини, тому що допомагають розробити конкретні шляхи для запобігання таким дефектам [4], так і для правосуддя, оскільки дозволяють захистити інтереси громадян від неправомірних посягань на їх життя та здоров’я [5]. Незважаю- чи на достатньо широкий інтерес щодо правової оцінки помилкової медичної допомоги з боку вчених-юристів [6, 7], медичні аспекти цієї проблеми мало досліджувались вітчизняними науковцямимедиками. У загальнодоступних та спеціалізованих наукових виданнях сьогодні відсутні дані щодо особливостей дефектів медичної допомоги, їх поширеності, причин чи наслідків стосовно лікарів певних фахів, в т. ч. серед лікарів-хірургів. Тому в представленому дослідженні зроблено спробу більш докладно висвітлити цю проблему.

Мета роботи: вивчити особливості недоліків у наданні медичної допомоги, які допускають 
лікарі-хірурги, що в подальшому стає підставою для відкриття кримінальних проваджень.

Матеріали і методи. Відповідно до мети роботи досліджено матеріали комісійних судово-медичних експертиз у випадках неналежного виконання професійних обов’язків лікарями-хірургами (так звані “лікарські справи”), проведених у Тернопільському обласному бюро судово-медичної експертизи (ТОБСМЕ) протягом 2007-2016 рр. Об’єктами для дослідження стали різноманітні медичні документи та матеріали кримінальних справ із Тернопільської, Хмельницької, Львівської областей, надані судово-слідчими органами цих регіонів для судово-медичної експертизи в умовах ТОБСМЕ. Зокрема: висновки експерта; акти судово-медичних досліджень; протоколи патологоанатомічних досліджень трупів; довідки про причину смерті; протоколи, висновки та рішення контрольно-експертних комісій; матеріали службової перевірки щодо якості надання медичної допомоги; протоколи допитів та пояснень лікарів; медичні карти стаціонарних хворих; медичні карти амбулаторних хворих; рецензї на історії хвороб; інші матеріали кримінальних справ. Усі ці документи піддано докладному аналізу, результати якого занотовано в окремі, спеціально розроблені формалізовані карти для кожного випадку неналежної медичної допомоги. Результати досліджень узагальнено, систематизовано та оброблено за допомогою загальностатистичних методів.

Результати досліджень та їх обговорення. Вивчено 126 комісійних експертиз у випадках скарг на неналежне виконання медичними працівниками своїх професійних обов’язків, виконаних у ТОБСМЕ протягом останнього десятиліття. Встановлено, що безпосередньо проти хірургів загального профілю кримінальні провадження було відкрито у 25,4 \% випадків, що знайшло відображення у матеріалах 32 досліджених справ та судово-медичних експертиз.

Практично у всіх досліджених справах (29, або 90,6 \%) судово-медичними експертними комісіями були виявлені різноманітні недоліки у наданні медичної допомоги. Під недоліками надання медичної допомоги розумілись будь-які упущення, промахи, дефекти, невиконання належним чином навмисно, підсвідомо чи ненароком професійних обов'язків медичними працівниками (лікарями або середнім медичним персоналом) [8, 9].

Як правило, порушення у професійній діяльності лікарів-хірургів спостерігались під час надання медичної допомоги хворим з ургентною патологією. Основна маса (75 \%) таких недоліків була допущена лікарями районних або міських лікарень, 12,5 \% - лікарями поліклінік, решта одиничних випадків - лікарями медичних закладів обласного рівня. Стосовно етапів надання медична допомога з дефектами зустрічалась частіше за все серед лікарів стаціонарів - 18 справ (56,2 \%); неправильні професійні дії з боку хірургів поліклінік, які в подальшому потягли помилки з боку хірургів стаціонарів - у 8 випадках (25 \%); дефекти з боку хірургів тільки поліклінік були виявлені в 4 випадках (12,5 \%). Найбільшу кількість хворих, хірургічну допомогу яким було надано 3 порушеннями, склали пацієнти з травмами різноманітного походження: грудної клітки, живота, черепа, кісток, м'яких тканин та їх ускладненнями.

Виявлені дефекти у наданні медичної допомоги виокремили за видом - діагностичні, лікувально-тактичні, організаційні, деонтологічні, недоліки у медичній документації [10] та за характером - ненадання медичної допомоги, несвоєчасне iї̈ надання, недостатнє надання та неправильне надання [11]. Як видно з рисунка 1, частіше за все хірурги припускались діагностичних помилок, питома вага яких серед інших дефектів медичної допомоги склала 35,4 \%, помилок у веденні медичної документації (23,5 \%), лікувально-тактичних помилок (20,6 \%), організаційних (17,6 \%), деонтологічних (2,9 \%).

Характерно, що неправильні дії лікарів зазвичай були асоційованими, коли, наприклад, хибність у діагностиці тягула за собою неправильне лікування і супроводжувалось також ще й недоліками у веденні медичної документації.

Серед недоліків діагностики траплялись недостатні загальноклінічні обстеження і лабораторні та інструментальні дослідження; поверховий збір анамнезу і нез’ясування механізму травми; недооцінювання клінічних проявів захворювання та об’єктивного стану хворого; необгрунтованість, неповнота, несвоєчасність або хибність клінічного діагнозу; непроведення показаних спеціальних додаткових методів обстеження та діагностики; “пропущення” як зовнішніх, так і внутрішніх ушкоджень і неправильна їх діагностика.

Лікувально-тактичні дефекти були пов’язані 3 технічними помилками під час операції; “пропуском” і неушиванням ушкоджень внутрішніх органів; непередбаченням розвитку ускладнень; хибністю медикаментозних призначень, серед яких слід відзначити: перевищення доз препаратів, у т. ч. наркотичних, недостатній чи надлишковий об’єм інфузій, необгрунтоване призначення багатьох лікарських засобів одночасно (поліпрагмазія). Серед інших неналежних дій в лікувальнотактичній сфері необхідно зазначити відсутність показань до операційного лікування, відсутність 


\section{Структура недоліків медичної допомоги за видами}

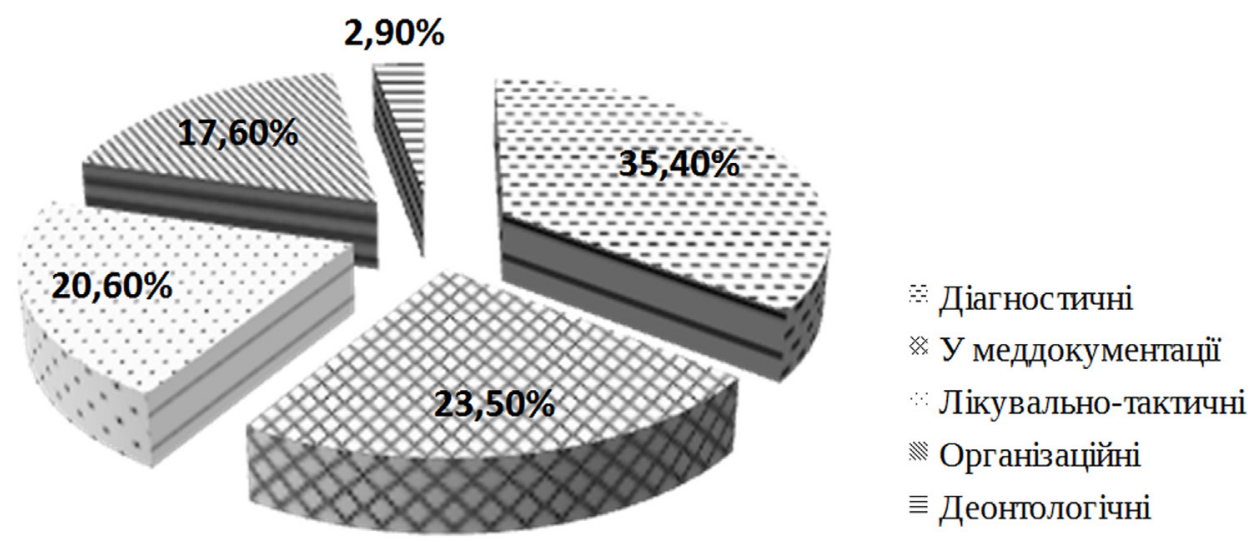

Рис. 1. Діаграма видової структури недоліків медичної допомоги, яка надавалась лікарями-хірургами.

даних моніторингового спостереження за пацієнтом, поганий післяопераційний нагляд, неправильний прогноз.

Організаційні упущення у наданні медичної допомоги виникали, коли лікуючі лікарі не використовували можливості консультантів та не скликали консиліум; неправильно скеровували госпіталізацію (не за профілем); порушували правила транспортування хворого (без супроводу медичного персоналу, не у санітарному транспорті, здійснювали транспортування за відсутності показань). Організаційними дефектами були також відсутність або несправність медичного устаткування; відсутність або недостатність контролю 3 боку адміністрації лікувального закладу за станом лікувально-діагностичного процесу; відсутність розтину у випадках сумнівного діагнозу чи нез’ясованої причини смерті.

Серед недоліків у веденні медичної документації траплялись недостатній виклад анамнезу захворювання (з несуттєвими подробицями, але відсутніми необхідними даними для правильної діагностики - наприклад, час захворювання, особливості його перших проявів чи симптомів, наявність супутньої патології тощо); відсутність дати, часу та змісту консультацій фахівців; поверховий і неповний опис об’єктивного статусу; відсутність інформованої згоди пацієнта на обстеження та лікування або відсутність письмової заяви про його відмову від лікування; невідповідність клінічного діагнозу діючій MKX або “скороченість” такого діагнозу; відсутність записів чергових лікарів або тривалий часовий проміжок між такими записами; невідображення динаміки захворювання у щоденних записах; непослідовність чи неповнота епікризу тощо. Окремо слід зауважити про незадовільне складання хірургами протоколів опера- ційних втручань. Оператори, як правило, поверхово, шаблонно і неприпустимо коротко відображали етапи операції; не вказували макроскопічні (морфологічні) властивості хворобливо змінених тканин та органів; описували абияк або взагалі не описували макропрепарати, особливості ушкоджень внутрішніх органів чи ранових каналів; не зазначали післяопераційний діагноз взагалі або не вказували у ньому патологоанатомічну сутність процесу. Звертає на себе увагу також невміння хірургами правильно описувати ушкодження у відповідному розділі об’єктивного статусу - Locus morbi. Замість докладного викладу морфологічних властивостей (яких є 10 - локалізація ушкодження, видова належність, форма, величина, особливості країв, особливості кінців, стан стінок, дна, навколишніх тканин) обмежувались лише їх констатацією. При цьому часто помилялись, оскільки слабко диференціювали, наприклад, садно і забій чи різану і колото-різану рани, тобто, абсолютно різні за своєю клінічно-анатомічною суттю ушкодження. Про особливості належної клінічної діагностики ушкоджень м’яких тканин нами раніше вже докладно було роз'яснено [12].

Серед деонтологічних помилок мала місце некоректна поведінка медичного персоналу з хворим чи його родичами та приховування пацієнтом або особами, які його супроводжували, даних про анамнез та особливості захворювання.

Таким чином, отримані дані свідчать, що найчастіше лікарями-хірургами допускались діагностичні та лікувально-тактичні помилки. Звертає на себе увагу значна кількість недоліків у веденні медичної документації, що зазвичай супроводжували всі інші види упущень у професійній діяльності хірургів. У зв’язку із цим необхідно знати, що історія хвороби є важливим юридичним 
документом, правильне ведення якого є прямим обов'язком кожного лікаря. Неправильне, помилкове, неналежне оформлення медичних документів трактується з точки зору кримінального права як один з проявів злочинного недбальства.

3 метою уникнення діагностичних помилок, лікарю-практику слід пам’ятати, що правильна діагностика складається з трьох невід’ємних і тісно пов'язаних між собою складових: анамнезу, семіотики і лікарської логіки. Помилки в діагностуванні стають неминучими, коли порушується ця послідовність або коли хоча б одна із вказаних ланок випадає. Щодо запобігання лікувально-тактичним недолікам, то доречно навести таку цитату з класичної монографії “Хирургические ошибки” (И. И. Краковский, Ю. А. Грицман, 1967) [10]: “Правильна хірургічна тактика складається із суми заходів, які дозволяють... в конкретній обстановці забезпечити найбільш оптимальне досягнення основної мети лікаря - вилікування хворого”.

Аналіз допущених лікарями недоліків медичної допомоги за характером показав, що недостатній обсяг цієї допомоги встановлено серед 47,7 \% справ, неправильність її надання - у 33,3 \%, несвоєчасність медичної допомоги констатовано у 19,0 \% випадків (фактів ненадання медичної допомоги у вивчених матеріалах виявлено не було). Такі дефекти зустрічались як поодиноко, коли в межах однієї “лікарської справи” був виявлений недолік лише одного типу (наприклад, несвоєчасна медична допомога), так і комбіновано, коли медична допомога одночасно була недостатньою, неправильною та несвоєчасною.

Оцінка дій медичних працівників судово-медичними експертними комісіями, як і належна правова кваліфікація таких дій чи бездіяльності, неможлива без з'ясування їх причин, наслідків, до яких вони призвели, та знаходження відповідних причинно-наслідкових зв’ язків.

Причини неналежного виконання лікарями своїх професійних обов’язків прийнято поділяти на дві групи: об’єктивні та суб'єктивні. До об’єктивних належать такі причини, які зумовлені недостатнім розвитком медичної науки та практики, існують поза свідомістю людини і виникли незалежно від волі, професійності та особистісних якостей лікаря $[4,9,10,11]$. За результатами проведеного дослідження, об'єктивними причинами недоліків у наданні медичної допомоги в хірургії були: тяжкість стану пацієнта, запізніле звернення за медичною допомогою, труднощі діагностики, нетиповий перебіг патологічного процесу та відмова хворих або їх родичів від госпіталізації.
Суб’єктивні причини пов'язані з особливостями лікаря, які похідні від його діяльності, залежать від ступеня професійної підготовки [4, 9, 10, 11]. До таких причин віднесли підтверджені експертними висновками неправильні, неналежні, всупереч медичній науці професійні дії хірургів, що було виявлено в 50,0 \% випадків. Окремо необхідно зазначити, що кожна третя “лікарська справа” виявила різноманітні за обсягом та глибиною порушення галузевих стандартів і протоколів надання медичної допомоги чи посадових інструкцій, що під час правової оцінки відповідних дій медичного персоналу завжди є обтяжуючим фактором.

Виявлені недоліки у наданні медичної допомоги хірургічним хворим майже завжди супроводжувались тяжкими для пацієнтів наслідками (93,7 \% випадків). Зокрема, смерть пацієнта констатовано в 78,1 \% справ; заподіяння тяжкого тілесного ушкодження - 3,1 \%; спричинення тілесного ушкодження середнього ступеня тяжкості у 12,5 \%. Причиною смерті в більшості випадків дефектної медичної допомоги стали: поліорганна недостатність на грунті перитоніту чи інфекційнотоксичного шоку, тромбоемболія легеневої артеpiї, гостра ренальна чи печінкова недостатність, набряк головного мозку. Такі хворі часто помирали протягом перших 6-ти діб після операції (тобто, в ранньому післяопераційному періоді).

3 точки зору кримінального права, необхідно знати, що далеко не кожний випадок несприятливого лікарювання повинен ставати підставою обвинувачення лікаря в злочинному недбальстві. Несприятливий наслідок нерідко залежить не від конкретних дій лікаря, а від ряду об’єктивно-випадкових подій. Кримінальна відповідальність настає, коли, крім тяжкого наслідку для пацієнта, встановлено конкретне упущення з боку професійної діяльності лікаря та причинно-наслідковий зв'язок між неправильними діями (бездіяльністю) цього лікаря та несприятливим наслідком для його пацієнта.

Прямий чи опосередкований причинно-наслідковий зв’язок між недоліками у наданні медичної допомоги лікарями-хірургами та негативними наслідками був встановлений судово-медичними експертними комісіями майже в кожному другому випадку, що склало 40,6 \% вивчених слідчих справ.

Висновки. 1. Різноманітні порушення лікарямихірургами власних професійних обов’ язків виявлено практично в кожній, порушеній проти них, кримінальній справі (90,6 \% усіх таких справ). Це свідчить про невисокий рівень медичної допомоги, яка надається хірургами, і вимагає його покращення. 
2. Недоліки медичної допомоги допускали зазвичай хірурги районних і міських лікарень та поліклінічних відділень, у хворих з ургентною хірургічною патологією, серед якої переважали пацієнти з травмою органів грудної і черевної порожнин, м’яких тканин та кісток скелета.

3. Як правило, неправильні професійні дії лікарів-хірургів були асоційованими, зустрічались під час діагностики, лікування, в оформленні медичної документації та в організаційному забезпеченні медичних заходів. Медична допомога з дефектами зазвичай надавалась у недостатньому обсязі, неправильно та несвоєчасно.

\section{СПИСОК ЛІТЕРАТУРИ}

1. Москаленко В. Ф. Медичне законодавство: правова регламентація лікарської діяльності / В. Ф. Москаленко, Б. В. Михайличенко. - К. : ВСВ “Медицина”. - 2011. - 495 с.

2. Флоря В. Н. Судебно-медицинская экспертиза по делам о “врачебных преступлениях” / В. Н. Флоря // Медицинское право. - 2009. - № 2. - С. 37-41.

3. Хміль І. Ю. Законодавче забезпечення лікарської діяльності : навч. посібник / І. Ю. Хміль, Б. В. Михайличенко, О. І. Артеменко. - К. : ВСВ “Медицина”, 2010. - 208 с.

4. Завальнюк А. Х. Етично-правові аспекти лікарської діяльності в Україні : монографія / А. Х. Завальнюк, Г. Ф. Кривда, І. О. Юхимець. - Одеса : Астропринт, 2008. - 192 с.

5. Синиця В. В. Шкода, спричинена лікуванням: деякі медико-правові аспекти / В. В. Синиця // Адвокат. - 2012. - № 3 (138). - C. 24-26.

6. Антонов С. В. Неудачное медицинское вмешательство: кто и за что понесет ответственность / С. В. Антонов // Медична практика: організаційні та правові аспекти. - 2010. № 6. - С. 46-49.

7. Сенюта I. Я. Право людини на медичну допомогу: деякі теоретико-практичні аспекти // Медичне право України: правовий статус пацієнтів в Україні та його законодавче забезпе-
4. Більшість випадків різноманітних упущень з боку лікарів-хірургів супроводжувалась розвитком тяжких наслідків для пацієнтів. Причиннонаслідковий зв'язок між неналежними діями хірургів та негативними наслідками виявлено в 40,6 \% “лікарських справ”.

5. Проблема недоліків медичної допомоги в хірургії потребує подальшого вивчення з метою своєчасного їх виявлення, аналізу й обговорення у лікарських колективах, що дозволить розробити ефективні профілактичні заходи для запобігання таким порушенням та суттєво покращить ефективність і якість надання хірургічної допомоги громадянам.

чення (генезис, розвиток, проблеми і перспективи удосконалення) : матеріали II Всеукраїнської науково-практичної конференції (Львів, 17-18 квітня 2008 р.) / упоряд. І. Я. Сенюта, Х. Я. Терешко. - Львів : Видавництво ЛОБФ “Медицина і право”, 2008. - С. 277-283.

8. Завальнюк А. Х. Професійні правопорушення медичних працівників: аналіз ситуації, зміст поняття, пропозиції / А. Х. Завальнюк, І. О. Юхимець, О. Ф. Кравець // Український судово-медичний вісник. - 2009. - № 2. - С. 30-34.

9. Пашинян Г. А. Профессиональные преступления медицинских работников против жизни и здоровья / Г. А. Пашинян, И. В. Ившин. - М. : Медицинская книга, 2006. - 196 с.

10. Краковский И. И. Хирургические ошибки / И. И. Краковский, Ю. А. Грицман. - М. : Медицина, 1967. - 192 с.

11. Щёголев П. П. Судебно-медицинская экспертиза ненадлежащей медицинской помощи : автореф. дисс. на соискание учёной степени доктора мед. наук : спец. 14.01.25 “Судебная медицина” / П. П. Щёголев. - Гродно, 1974. - 49 с.

12. Франчук В. В. Ушкодження м’яких тканин: клінічні і правові аспекти діагностики та описання у первинних медичних документах / В. В. Франчук // Шпитальна хірургія. - 2008. № 1. - С. 109-115. 